\title{
CAPITAL STRUCTURE, A PEANACEA FOR SME'S GROWTH. (A STUDY OF SELECTED SME'S WITHIN ABEOKUTA METROPOLIS)
}

\author{
OKE Michael Ojo PhD. and ADEBAYO Adeyinka Taoheed \\ ${ }^{1,2}$ Ekiti State University, Ado-ekiti, Ekiti State
}

DOI: http://dx.doi.org/10.38193/IJRCMS.2021.3507

\begin{abstract}
This paper critically examined the impact of capital structure on SMES Growth, with specific focus on Kotco Energy Nig LTD and First Vending Nig Ltd, Abeokuta. This study employed a descriptive survey design. A sample size of 85 respondents was selected using simple random sampling technique of which 85 respondents filled and returned the questionnaire. Data from the questionnaire was analyzed using special software for statistics which is called statistical package for social science (SPSS) version 20. The study found out that there exists a strong relationship between capital structure and SME's growth, that there is a relationship between Government Scheme and SMES Growth and therefore recommends that Government should provide adequate stimulus and relieve package to SMES so as to enable their businesses thrive. This could be achieve through several scheme and reforms for the benefits of small scale businesses also the study recommends that To have an effective capital structure or financing for SMES, compulsory levies such as tax, space levy should be reduced to a minimal point so as to assist small scale businesses have adequate capital for investment.
\end{abstract}

KEYWORDS: Capital structure, Government Scheme, Assets, Equity Ratio, Debt Ratio and SMES Growth.

\section{Background of Study}

The rate of growth in Nigeria economy cannot be fully investigated without a closer look at the contribution of capital formation to Nigeria's economic growth. This is in the understanding that capital structure has been recognized as an important factor that ascertain the growth of Nigerian as well as the Ogun State economy.

No country has achieved sustained economic growth without substantial investment in capital structure. In a bid to determine economic growth around the globe, emphasis has been placed on increased capital structure. Nevertheless, understanding the determinants of the capital structure is very germain in designing a number of policy interventions towards attaining economic growth.

Capital structure, in finance, refers to the way a corporation finances its assets through the aggregate of equity, loan, or hybrid securities. It is the ratio of different kinds of securities raised by a firm as 
long-term finance. The capital structure of a firm described the combination of both loan and equity finance structure of the firm. A firm's capital structure is therefore the composition or 'structure' of its liabilities. Capital Structure is an important tool for SMEs and large businesses. It is however important to note that accessibility of capital to SMEs will trigger economic growth and development, Ajao, (2013).

With a combination of various sources of capital like ordinary shares, preference shares and long-term fund a number of considerations requires to be put in place as far as optimum capital structure is concerned. This combination of sources of capital makes it hard for a firm on realizing the goal of utilizing funds economically. Therefore, it is progressively relied that a firm need organizes and control its capital structure for an optimum use of funds and to be in a position that enhance dealing with upcoming situation (Pandy 2009). Management and owners keeps on making decisions on proportions of loan versus equity as they try to get answers to the following questions; so as to get higher returns, should they go for more loan? To reduce risk of high gearing, should the firm use more equity finance? A rise in value of a firm by restraining managers to work at shareholder's interest decrease agency costs outside equity by high leverage or low equity/asset ratio. The two major types of liabilities are equity and loan and the holders represent the two classes of firm's investors. Different levels of risks, gains and influence have an relationship for each of the two liabilities. Loan owners have no control over the firm's operations, they earn fixed rate of interest according to the terms and conditions of the investment contract. Ordinary shareholders are the last claimant and bears nearly all the risks even though they have greater influence to the firm's operations. Reserved earnings on the other hand is part of equity fund that is generated internally only when a firm makes profit and in a position to reserve some of the earnings for future use. Therefore, a firm that makes no profit cannot raise any reserve earnings (Abor, 2005). The study focused on three independent variables that includes equity capital, debt capital and retained earnings that forms part of capital structure (Ebaid, 2009).

Due to poor management of short-term loan, trade credit and long-term loans, SMEs have always experienced some difficulties in improving their financial performance. The cause could be failure by SMEs not using appropriate debts in their normal operations and if this is not rectified with, it may cause financial distress and business failure (Pindalo, 2006). However, the much availability of loan facilities and the strict procedure of raising the limited available equity finance has caused many SMEs to turn to debt as a source of finance (Githaiga 2015). This fact is theoretically and practically acceptable from the debt providers' perspective owing to the perceived high risk of moral concrete issues among small and medium enterprises. Debt is an important factor for the free flow of cash in the operation of the SMEs. Therefore, this study contributes to the literature by addressing the existing financing gap and attempts to diagnose the issue of access to finance and sources of finance accessible and available to SMEs. It is based on this background that the study was aimed to investigate the effect 
of capital structure on SME's Growth.

\section{Statement of Research Problems}

Today more than ever before the small and medium scale enterprises (SMEs) is pivotal to the economic development of the nation, almost $80 \%$ of the total population of Nigeria are either selfemployed or running a small and medium scale business in one or the other segment of the economy (kehinde, 2003). The SMEs also contribute firmly to the national economic productivity, and it is the bedrock of economic growth and development. The means of financing the SMEs remain an issue to many owners of the SMEs, they often start the firms using seed-capital from either personal saving, retirement benefit, family and other relations, sometimes less often than not the start-up capital are provided by loans from financial institutions. The experience in SMEs growth has shown that the entry-exit rate is very high in SMEs' development. The SMEs have most times been bedeviled by poor funding by the proprietors (at the growth stage) since all the sources available to them have limited funding capacity. The need, therefore, to the business using loan finance remains vital to the expansion, growth and improved earning structure of SMEs. To ensure that the SMEs develop and increase, government of Nigeria over the past forty years have implemented diverse developmental schemes pertaining to funding, management and marketing of services and products by the SMEs, however, the resultant effect of the supportive and developmental schemes of the government have been very low. Most SMEs have an all-equity financial structure over many years as they could not assess debt finance from the private financing institutions (Commercial banks), as well as from the government funding scheme partly due to stringent conditions by the commercial banks and the poor implementation of government schemes. It is generally known that small businesses are able to borrow from formal financial avenues such as banks or informal avenues like family and friends to increase their capital. SMEs' inability to gain access to bank loans could be due to high collateral requirements, high interest rates, and lack of relationship with bankers. There is no doubt that SMEs face increasingly large number of constraints and have less access to formal sources of external finance, thus accounting for the limited development potential of SMEs.

\section{Research Purpose and Objectives}

The main purpose of this research work is to access the role of capital structure on SMEs Growth in Ogun State, in line with this, the study stands out to investigate the following objectives:

1. To find out if there is a significant relationship between capital structure and SMEs Growth.

2. To investigate if there is a significant relationship between Government Schemes and SME'S Growth.

\section{Research Questions}

The above stated objectives necessitates the following research questions to be asked: 
1. Is there a significant relationship between capital structure and SMEs Growth?

2. What is the relationship between Government Schemes and SMEs Growth?

\section{Research Hypotheses}

The following are hypothetical statement of the study:

H1: There is a significant relationship between capital structure and SMEs Growth

H2: There is a significant relationship between Government Schemes and SMEs Growth.

\section{Significance of the Study}

The findings of the study are germain to SMEs and Governments as it assesses whether the capital structure strategies it has adopted have been beneficial to them or not thus coming up with appropriate pricing policies. The government can understand how manufacturing firms use pricing strategies to gain competitive edge due to intense competition from local and foreign firms and hence their sustainability. It is, thus, in a position to formulate policies that are aimed at increasing productivity and safeguarding their interests based on quality checks.

The development partners (banks) who are majorly interested at helping the organizations to advance can have an understanding of a wide variety of factors that hinder them hence sustainability and the extent to which the identified factors affect their operations. The scholars and researchers who would like to debate or carry out more studies on pricing strategies used by firms to enhance their growth and development.

\section{LITERATURE REVIEW CONCEPTUAL REVIEW}

\section{Capital Structure: Overview}

Capital structure means the proportionate use of loan and equity in financing organization operation (Kennon, 2010). These sources of fund include equity and liabilities which are presented in the statement of financial position. Huang and $\mathrm{Vu}$ Thi (2003) classified these sources of fund into: retained earnings (internal equity); issuing new shares (external equity); and borrowing through debt instruments (debt capital). The proportion of each of these components has diverse impact on the success of the firm. The impact of this capital structure mix on firm financial performance can be evaluated on the basis of the benefits and cost associated with each component of fund. Premised on this, managers are often saddled with a major task of designing appropriate capital structure mix which will increase the firm financial performance. According to Myer and Majluf (1984), management often takes into consideration all means of financing available having in mind the least expensive source. The relevance of an optimum capital mix was also emphasized by Chowdhury and Chowdhury (2010) when they opined that in order to maximize the firm value, profitability and shareholders wealth, suitable mix between loan and equity financing cannot be undermined. The findings of empirical 
research on the impact of these capital structure components on firm financial performance have been mixed, however each of these findings have implication for policy formulation.

Capital structure determines how the company is financing its operations and investments. The capital structure combines diverse securities, such as equity, loan and hybrid securities (Hillier et al., 2011). Equity is defined as a security that represents ownership interest, such as common stock. Loan is defined as the amount borrowed from one party to another. Loan can be classified by the maturity time: if the maturity of loan is more than 12 months, then it is classified as long-term, such as bond or loan agreements, otherwise, it is classified as short-term, for example as notes or in some cases bank loans. The hybrid securities exhibit the characteristics of both loan and equity, for example, convertibles or preferred stock. This study will focus on the loan in order to measure capital structure, mainly total debt, short-term debt and long-term debt.

\section{The Determinants of Capital Structure}

These attributes are denoted growth opportunities, size, profitability, tangibility and non-debt tax shields. These determinants and indicators are discussed below.

Growth Opportunities Jensen and Meckling (1976), Myers and Majluf (1984), and Fama and French (2000) argue that firms with high future growth opportunities should use more equity financing, because a higher leveraged company is more likely to pass up profitable investment opportunities. The trade-off model predicts that firms with more investment opportunities have less leverage because they have stronger incentives to avoid underinvestment and asset substitution that can arise from stockholder-bondholder agency conflicts. The trade-off theory predicts a negative relationship between leverage and investment opportunities. Pecking order theory suggests also that a firm's growth is negatively related to its capital structure. Growth opportunities may be considered assets that add value to a firm, but cannot be collateralized and are not subject to taxable income. The agency problem suggests a negative relationship between capital structure and a firm's growth.

Firm's Size Many authors have suggested that the leverage ratio may be related to firm size. However, there are conflicting results on the relationship between firm's size and leverage. The trade-off theory predicts that larger firms tend to be more diversified, less risky and less use to bankruptcy. Firms may prefer loan rather than equity financing for control. Control considerations support positive correlation between size and leverage. Thus, large firms should be more highly leveraged. In the literature, the natural logarithm of net sales or total assets, average value of total assets, total assets at book value and the market value of the firm were used as measure firm size (Sayilgan et al., 2006).

Profitability Most of the empirical studies show that there are no consistent theoretical forcasting on the effects of profitability on leverage. In the trade-off theory, more profitable firms should have 
higher leverage because they have more income to shield from taxes. The free cash-flow theory would suggest that more profitable firms should use more loan in order to discipline managers, to expose them to pay out cash instead of spending money on inefficient projects (Bauer, 2004). Thus, some of empirical studies finds a positive relationship between leverage and profitability, for example (Taub, 1975; Fattouh et al., 2002). However, in the pecking-order theory, firms prefer internal financing to external. So more profitable firms have a minimal need for external financing and therefore should have lower leverage (Bauer, 2004).

\section{Small and Medium Scale Business Environments in Nigeria and Its Supports}

The term enterprise refers to any social activity whose major goal is to offer services or produce goods within the framework of a community or society. The exact type of business that takes place in a given society is largely determined by the attitudes, needs and beliefs of members of such community. In real life situation, the society makes demand on the business and vice versa. The term business environment refers to the interrelationship that exists between the community and the business establishments that operate within the community. Nevertheless, it is imperative to know that the support and specific business environment differs from one geographical location to another. So, while some business environments may be hostile, others can be very favourable for the growth of business. The conceptual meaning of the term business environment is quite complex. Thus, business environment ought to be dynamic, so that it can be compatible with the independent actions of all organizations and institutions as well as individuals that have both direct and indirect effects on business operations (Olson 1987). Furthermore, Olson (1987) identified the various stakeholders that are involved directly or indirectly in the country's business environment as follows:

- The Individuals, which include customers that are in needs of the services or goods offer by a business organization; employees that provides the necessary entrepreneurial skills needed for the provision of services and production of the goods.

- The business establishments, which are primarily responsible for supply of services and input necessary for production, distributions and subsequent retailing of the goods and services. Most time, these stakeholders also act as competitors in the market.

- The state, which includes regulators of the economy, employers, producers and consumers of services and goods etc.

In his study, Aluko (1983) identified two broad categories of business environment. These are internal business environment and external business environment. According to him, the internal business environment consists of technologies and tools that are used by organization for normal business dealings. Examples of components of the internal environment include control procedures, administrative procedures, production system, products, service, marketing procedures and the market itself. On the other hand, Aluko (1983) listed some components of external business as follows: 
government regulatory system, ethical system, technological system, social system, economic system, legal system, political system, customers and competitors in the same business environment. But most importantly, Aluko (1983) pointed out that the business is strongly related to its environment. In other words, the two are somewhat interdependent.

As a developing country, Nigerian business environment is constantly changing. Such change, whether negative or positive, can either offer more opportunities or generate more threats for the existing businesses. This partly explains why the decision taken by many business organizations are greatly influenced by various elements of external and internal business environment. It also explains the interdependence between business and its environment. Ajayi and Adebisi (2006) observed that this interdependence is essential for adequate understanding of how business functions as well as how policies are being formulated. Base on the above assertion, Isimoya (2005) affirms that the business operations involved two basic institutions namely: the market environment and the company. In this case, the company is mainly responsible for dispatching services, goods and information (communication) to the market. In return, the market generates feedback and sales (money) for the company. In his study, Obikoya (1995) pointed out that the existence of other elements, which are very much capable of influencing the company and market. According to him, such elements are the primary determinants of the actual services which the company has to offer in the market, and ultimately attain success. He identified competitive environment, which consists of intermediaries and industry, as the first of such element. For example, the company's level of success in its normal business operation is primarily determined by the materials, capital, efficiency of suppliers/distributors and competitiveness for labour in the industry. Obikoya (1995) also pointed out that the second stage of environmental elements are found mainly in the micro-environments. In this scenario, macroenvironments simply refer to independent institutions that can advance the operations of a business organization. Typical examples include market intermediaries, insurance firms, financial institutions, members of the public. The last and most general level of environmental forces identified by Obikoya (1995) is the macro environment.

The various elements of the business environment can have considerable effect on the firm's performances, conduct and structure. In fact, it is practically impossible for any business to operate effectively without them. This is one of the major reasons why it is very essential for every business to establish operational structures that will enable them adapt to any changes in the market. The success of any business organization depends largely on the levels, to which it is fine-tuned to its environment. The term innovative is generally used to describe any firm that take advantage of the opportunities that comes with change, and overcome any threats that come with such change. Thus, a business can only be prosperous, if it is innovative and adaptive. This is illustrated by Amuda (2006), as he strived to revealed the inter-dependence between the company and its environment, and went further to explain the open system concept. 


\section{Capital Structure Elements and Business Financial Performance: Overview}

The study examines Leverage and Equity as it affects Business Financial Performance. These are further discussed below:

\section{Leverage and Business Financial Performance}

Financial leverage is level operating assets are financed with loan versus equity (Penman, 2001). Loan financing has a mandatory call on firm's cash by means of interest payment and principal repayment. The mandatory call on loan financing is represented by cost of borrowed fund which should be efficiently covered by the firm earnings capacity. The higher a firm's leverage, the higher the bankruptcy risk in down times thus the higher the profits in good time for equity provider. The findings of leverage on financial performance is mixed. Specifically, the study of Rehman (2013) indicated that as loan financing increases, there is a corresponding rise in fixed interest cost, thus undermining profit. In same vein, the study of Rajin (2012) corroborates the findings of both Rehman (2013) and Akhtar et al. (2012). Using shareholders return and market capitalization as performance indices, the study revealed that leverage and shareholders return exhibit positive relations while leverage and market capitalization had a negative relationship. Other studies that corroborate positive relationship between leverage and financial performance are: Hadlock and James (2002), Ghosh and Jain (2000), Berger and Bonaccorsi (2006). The reason adduced to this unexpected result is that as debt level increases due to the introduction of new capital by borrowings, firms are able to use these borrowed funds to the level that the gains surpass the expected cost of such fund (Hutchinson, 1995). However, to Hadlock and James (2002), flexibility at which firms adjust its loan usage in down time also determines the impact it will have on earnings. For instance, when a capital structure is over burdened with long term loans, it may become hard to adjust its loan usage within a relatively short time should there be decline in its earnings power, thus interest cost exhibiting a constrain on earnings. Conversely, if there is moderate debt mix over a relatively short period, decline in earnings power during down time will only short-lived because most of these firms will fully come to terms with the need to properly position by adjusting its debt usage, thus restoring the balance between cost of loan and earnings power.

\section{Equity and Business Financial Performance}

The effect of equity on financial performance could be likened to the effect of ownership structure on firm financial performance. Equity financing refers to share ownership which is atomistic in nature. It could be highly dispersed or concentrated i.e. before now, there are many owners with few holding few unit of shares unlike the latter in which there are few shareholders with each having large unit of shareholdings (institutional shareholdings). Gursory and Aydojan (2002) also gave two dimensions to this type of ownership: ownership concentration which refers to the share of the largest owner and it is influenced by absolute risk and minority cost (Pederson and Thomsen, 1999); and ownership mix 
which refers to the identity of major shareholders. Despite of the nature of equity ownership, earlier studies have linked firm financial performance to it though their findings seem not to be in tandem with one another. Studies such as Loderer and Martin (1997), Demsetz and Villalonga (2001), Bohren and Odegaard (2000), Cho (1998) have examined ownership structure and financial performance from bidirectional approach. Specifically, the study of Loderer and Martin (1997) address the causality between firm value and managerial ownership and the result from the two stage least square (2sls) regression revealed no significant evidence of managerial ownership on performance, in contrast performance exhibits a negative effect on executive stockholdings.

\section{THEORETICAL REVIEW ON CAPITAL STRUCTURE}

The study focused on three (3) theory which are pertinent to Capital Structure and these theories include: Modigliani-Miller Theory, Agency cost theory and Pecking Order Theory. The rationale behind the adoption of these theories is the fact that these theories emphasize firm financial decisions and as well as capital structure. The details of these theories are therefore given below:

\section{Modigliani-Miller Theory}

Discussion on the theory of capital structure was started by the fundamental work of Modigliani and Miller (1958). The theory is based on the following assumptions: first, the markets are frictionless markets, meaning there are no transaction costs; secondly, the markets are competitive, and individuals and firms are price takers; thirdly, individuals and firms can undertake financial transactions at the same prices (e.g., borrow at the same rate; fourth, all agents have the same information; lastly there are no taxes.

These assumptions deductively led to the famously recognized idea of the "capital structure irrelevance" where the debt has no influence on the firm's value under the efficient market assumption. The Modigliani \& Miller proposition demonstrates that by taking companies investment policy as given, in the perfect market, without tax, transaction cost and with all of the information, capital structure has no effect on the firms' value. However, each of these assumptions does not hold true in the "real world". Modigliani and Miller realized the limitations of the original model and decided to include taxes into the equation. This resulted in the unrealistic proposition that the firm has to be financed by $99.99 \%$ of debt in order to increase its value (Modigliani and Miller, 1963). By just "relaxing" one of the assumptions, it is evident that capital structure is important for a firm's value. In the case when all the assumptions are realistic, capital structure has an influence on the value of a firm. Agency Cost theory Jensen and Meckling (1976) developed agency cost theory. Agency costs are described as the total of the monitoring expenditures by the principal, bonding costs by the agent, and a residual loss. Agency problem arises because of the conflicts either between managers and firm owners (agency cost of equity) or between firm owners and debt holders (agency costs of debt). 
According to agency theory, there are several problems that are connected to debt. The first one is referred to as an overinvestment problem or "free cash flow theory". Due to the separation of ownership and control managers are more inclined to maximize their utility, rather than act in the interest of the firm. As Jensen (1986) specified "the problem is how to motivate managers to disgorge the cash rather than investing it below the cost of capital or wasting it on organizational inefficiencies." Debt capital is argued to be a way to control agency cost. In this case, leverage will act as a corporate governance mechanism and will force managers to pay out the required interest payments by performing and generating cash. According to Gansuwan \& Önel (2012), debt serves as a way to encourage managers to align their actions with the interests of shareholders by constraining the managers. Thus, interest payments will reduce the amount of available cash flows for managers to spend on empire building or other projects with negative NPV (Jensen, 1986). Another implication of greater financial leverage is that it may affect managers and reduce agency costs through the threat of liquidation, which causes personal losses to managers of salaries, reputation, perquisites (Grossman and Hart, 1982). Therefore, the theory postulates that high amount of debt contributes to reducing firm's agency costs and provides mitigation of agency conflicts.

\section{Pecking Order Theory}

The trade-off and the pecking order theories try to explain the financing decisions in firms. The tradeoff theory assumes that the optimal capital structure can be visualized as a trade-off between the benefit of debt financing and the costs of debt financing. Each firm should set its target capital structure such that its costs and benefits of leverage are balanced at the margin, because such a structure will maximize its value (K. Acaravci, 2007). The trade-off theory of the capital structure suggests that a firm's target leverage is driven by three competing forces: (i) taxes, (ii) costs of financial distress (bankruptcy costs), and (iii) agency conflicts. Adding debt to a firm's capital structure lowers its (corporate) tax liability and increases the after-tax cash flow available to the providers of capital. Thus, there is a positive relationship between the tax shield and the value of the firm. Firms attempt to balance the tax benefits of higher leverage and the greater probability of financial distress (Drobetz and Fix, 2003).

\section{EMPIRICAL REVIEW}

Many studies have been conducted locally and internationally in this area of study with the view of helping both growing and grown firms structuring their finances efficiently. This section of the study is therefore concerned with looking at some of those studies as follows.

In the first place, Onaolapo and Kajola (2010) conducted a study on the impact of capital structure and performance of Nigerian firms focusing only on the non-financial firms for a period of seven year (2001-2007) from agency cost theory point of view. The study revealed that capital structure surrogated by debt ratio (DR) has a significantly negative impact on firm's financial measures, return 
on asset (ROA), and return on equity (ROE). This result provides evidence in support of agency cost theory. Pratomo and Ismail (2006) studied on the capital structure-and the performance of Islamic Banks of Malaysia. Profit efficiency of a bank was set as an indicator of reducing agency cost and the ratio equity of a bank as an indicator. of leverage. Their findings are in consistent with the agency hypothesis i.e. higher leverage or a lower equity capital ratio is associated with higher profit efficiency. Berger and Wharton (2002) in the same vein, studied on the capital structure and firm performance testing agency cost theory hypothesis with a complete attention on the banking sector. Findings here are as well consistent with the agency costs hypothesis - higher leverage or a lower equity capital ratio is associated with higher profit efficiency.

Also, Oke and Afolabi (2011) investigated the impact of capital structure on industrial performance in Nigeria taking five quoted firms into account with debt financing equity financing and debt/equity financing as proxies for capital structure while profit efficiency a surrogate for performance. For equity and debt equity finances, a positive relationship existed but a negative relations hip between debt financing and performance. besides, Anup and Suman (201 0) find out the impact of capital structure on the value of firm in the context Bangladesh economy or industrial sector by gathering secondary data of publicly listed companies traded in Dhaka Stock Exchange (DSE) and Chittangong Stock Exchange (CSE) using share price as a proxy for firm's value and different ratios for capital structure decision. It was found that maximizing wealth for the shareholders require perfect combination of loan and equity and that cost of capital is negatively correlated and therefore to be decreased to minimum level.

Furthermore, Ong and Teh (2011) investigated on the capital structure and firm performance of construction companies for a period of four years (2005-2008) in Malaysia. Long term loan to capital, loan to capital, loan to asset, loan to equity market value, loan to common equity, long term loan to common equity were used as proxies as the independent variables (capital structure) while return on capital, return on equity, earnings per share, operating margin, net margin were used to proxy the corporate performance. The result shows that there is relationship between capital structure and corporate performance. In Jordan, Zeitun and Tian (2007) conducted a study on capital structure and corporate performance on 167 Jordanian Firms between 1989-2003.

They found a significantly negative relationship between capital structure and corporate performance. Many variables such as ROA, ROE, PROF, Tobin's Q, MBVR, MBVE, PIE was used to measure performance while leverage, growth, size, tangibility, STDVCF were proxies for capital structure. Dare and Sola (2010) studied on the actual impact of capital structure on firm performance on Nigerian Petroleum industrial sector. Earnings per share and dividend per share surrogated performance while leverage ratio proxied capital structure. The study reported a positive relationship between the variables employed. In Sri Lanka, Pratheepkanth (2011) carried out an investigation on capital 
structure and financial performance of some selected companies in Colombo Stock Exchange between 2005 - 2009.

\section{GAPS IN LITERATURE}

What we found with the majority of these studies is that, they are sectorial focusing, like the studies of Pratomo and Ismall (2006) focusing on the Islamic Banks of Malaysia, Berger and Wharton (2002) on only the banking industry of US, Ong and Teh (2011) studied on the Bangladesh construction companies, Dare and Funso (2010) concentrated on the Nigerian petroleum industry, Onimisi (2011) concentrated on the Nigerian manufacturing firms only and Akintoye (2008) focusing only the Nigerian Food and Beverages industry. Besides, the aforementioned studies mostly have relatively small sample as in the case of Oke and Afolabi (2011) where a sample of five (5) firms: Guinness Nigerian PLC, Cement Company of Northern Nigerian PLC, First Aluminium Nigeria PLC, Longman Nigeria PLC and United Nigeria Textiles PLC chosen from breweries, building materials, industrial and domestic materials, printing and for publishing and textiles industries respectively.

Therefore, with these gaps observed from these studies, this study tries to bridge those gaps by studying top SMEs in ogun state and by touching all sectors (financial and non-financial) in order to increase the population of the study, thereby having a larger sample in the study and eventually allowing the findings to stand a better chance of being generalized on the Nigerian economy

\section{RESEARCH METHODOLOGY}

A descriptive research design was used in this study. The target population of this study comprises of the general staff of Kotco Energy Nig LTD and First Vending Nig Ltd, Abeokuta. However, a sample size of 85 was determined using the simple random technique and was shared equally between firms. This study is expected to produce both quantitative and qualitative data. Once the questionnaires are received they were coded and edited for completeness and consistency. Quantitative data was analyzed by employing descriptive statistics and inferential analysis using statistical package for social science (SPSS) version 20. This technique gives simple summaries about the sample data and present quantitative descriptions in a manageable form, Gupta (2004). Together with simple graphics analysis, descriptive statistics form the basis of virtually every quantitative analysis to data, Kothari (2004). The significance testing was done at 5\% level of significance and SPSS was used for this purpose.

\section{FINDINGS}

The following are analysis obtainable from respondent's opinions: 
ISSN 2582-2292

Vol. 3, No. 05 Sep-Oct; 2021

Government Schemes package is adequate and satisfactory in this organization.

\begin{tabular}{|l|r|r|r|r|}
\hline & Frequency & Percent & Valid Percent & $\begin{array}{c}\text { Cumulative } \\
\text { Percent }\end{array}$ \\
\hline \multirow{3}{*}{ Strongly Agreed } & 24 & 28.2 & 28.2 & 28.2 \\
Agreed & 22 & 25.9 & 25.9 & 54.1 \\
Undecided & 15 & 17.6 & 17.6 & 71.8 \\
Disagreed & 18 & 21.2 & 21.2 & 92.9 \\
Strongly Disagreed & 6 & 7.1 & 7.1 & 100.0 \\
Total & 85 & 100.0 & 100.0 & \\
\hline
\end{tabular}

Source: Survey, 2020.

The table shows that $28.2 \%$ of the respondents strongly agreed that government scheme package is adequate and satisfactory in this organization, $25.9 \%$ of the respondents agreed to the contrary, $17.6 \%$ of the respondents are unsure, $21.2 \%$ of the respondents disagreed to the subjected matter and $7.1 \%$ of the respondents strongly disagreed. This implies that majority of the respondents strongly agreed that government scheme package is adequate and satisfactory in this organization.

Capital Structure is essential to the growth SME's

\begin{tabular}{|ll|r|r|r|r|}
\hline & Frequency & Percent & Valid Percent & \multicolumn{2}{c|}{$\begin{array}{c}\text { Cumulative } \\
\text { Percent }\end{array}$} \\
\hline \multirow{4}{*}{ Valid } & & & 21.2 & 21.2 \\
& Strongly Agreed & 18 & 21.2 & 37.6 & 58.8 \\
& Agreed & 32 & 37.6 & 41.2 & 100.0 \\
Undecided & 35 & 41.2 & 100.0 & \\
Total & 85 & 100.0 & \\
\hline
\end{tabular}

Source: Survey, 2020.

The table shows that $21.2 \%$ of the respondents strongly agreed that Capital Structure is essential to the growth SME's, $37.6 \%$ of the respondents agreed to the contrary, $41.2 \%$ of the respondents are unsure. This implies that majority of the respondents where unsure that Capital Structure is essential to the growth SME's.

A major component of capital structure is Debt-Equity ratio.

\begin{tabular}{|c|c|c|c|c|c|}
\hline & & Frequency & Percent & Valid Percent & $\begin{array}{c}\text { Cumulative } \\
\text { Percent }\end{array}$ \\
\hline \multirow{5}{*}{ Valid } & Strongly Agreed & 23 & 27.1 & 27.1 & 27.1 \\
\hline & Agreed & 39 & 45.9 & 45.9 & 72.9 \\
\hline & Undecided & 8 & 9.4 & 9.4 & 82.4 \\
\hline & Disagreed & 15 & 17.6 & 17.6 & 100.0 \\
\hline & Total & 85 & 100.0 & 100.0 & \\
\hline
\end{tabular}




\section{Source: Survey, 2020.}

The table shows that $27.1 \%$ of the respondents strongly agreed that A major component of capital structure is Debt-Equity ratio, $45.9 \%$ of the respondents agreed to the contrary, $9.4 \%$ of the respondents are unsure, $17.6 \%$ of the respondents disagreed to the subjected matter. This implies that majority of the respondents agreed that A major component of capital structure is Debt-Equity ratio.

To a great extent capital structure enhances organizational performance and profitability.

\begin{tabular}{|c|c|c|c|c|c|}
\hline & & Frequency & Percent & Valid Percent & $\begin{array}{c}\text { Cumulative } \\
\text { Percent }\end{array}$ \\
\hline \multirow{6}{*}{ Valid } & Strongly Agreed & 27 & 31.8 & 31.8 & 31.8 \\
\hline & Agreed & 33 & 38.8 & 38.8 & 70.6 \\
\hline & Undecided & 10 & 11.8 & 11.8 & 82.4 \\
\hline & Disagreed & 13 & 15.3 & 15.3 & 97.6 \\
\hline & Strongly Disagreed & 2 & 2.4 & 2.4 & 100.0 \\
\hline & Total & 85 & 100.0 & 100.0 & \\
\hline
\end{tabular}

Source: Survey, 2020.

The table shows that $31.8 \%$ of the respondents strongly agreed that To a great extent capital structure enhances organizational performance and profitability, $38.8 \%$ of the respondents agreed to the contrary, $11.8 \%$ of the respondents are unsure, $15.3 \%$ of the respondents disagreed to the subjected matter and $2.4 \%$ of the respondents strongly disagreed. This implies that majority of the respondents strongly agreed that to a great extent capital structure enhances organizational performance and profitability.

SME's Growth is better enhanced through capital structure.

\begin{tabular}{|c|c|c|c|c|c|}
\hline & & Frequency & Percent & Valid Percent & $\begin{array}{c}\text { Cumulative } \\
\text { Percent }\end{array}$ \\
\hline \multirow{6}{*}{ Valid } & Strongly Agreed & 33 & 38.8 & 38.8 & 38.8 \\
\hline & Agreed & 26 & 30.6 & 30.6 & 69.4 \\
\hline & Undecided & 8 & 9.4 & 9.4 & 78.8 \\
\hline & Disagreed & 14 & 16.5 & 16.5 & 95.3 \\
\hline & Strongly Disagreed & 4 & 4.7 & 4.7 & 100.0 \\
\hline & Total & 85 & 100.0 & 100.0 & \\
\hline
\end{tabular}

Source: Survey, 2020.

The table shows that $38.8 \%$ of the respondents strongly agreed that SME's Growth is better enhanced through capital structure, $30.6 \%$ of the respondents agreed to the contrary, $9.4 \%$ of the respondents 
are unsure, $16.5 \%$ of the respondents disagreed to the subjected matter and $4.7 \%$ of the respondents strongly disagreed. This implies that majority of the respondents strongly agreed that SME's Growth is better enhanced through capital structure.

The combination of equity, debt, or hybrid securities leads to an effective capital structure.

\begin{tabular}{|ll|r|r|r|r|}
\hline & Frequency & Percent & Valid Percent & \multicolumn{2}{|c|}{ Cumulative } \\
\hline \multirow{2}{*}{ Strongly Agreed } & 37 & 43.5 & 43.5 & 43.5 \\
Valid & 23 & 27.1 & 27.1 & 70.6 \\
& Unreed & 7 & 8.2 & 8.2 & 78.8 \\
& Undecided & 14 & 16.5 & 16.5 & 95.3 \\
& Disagreed & 4 & 4.7 & 4.7 & 100.0 \\
& Strongly Disagreed & 85 & 100.0 & 100.0 & \\
\hline
\end{tabular}

Source: Survey, 2020.

The table shows that $43.5 \%$ of the respondents strongly agreed that The combination of equity, debt, or hybrid securities leads to an effective capital structure, $27.1 \%$ of the respondents agreed to the contrary, $8.2 \%$ of the respondents are unsure, $16.5 \%$ of the respondents disagreed to the subjected matter and $4.7 \%$ of the respondents strongly disagreed. This implies that majority of the respondents strongly agreed that the combination of equity, debt, or hybrid securities leads to an effective capital structure.

To a great extent government stimulus package is of immense benefit to the organization.

\begin{tabular}{|ll|r|r|r|r|}
\hline & Frequency & Percent & Valid Percent & $\begin{array}{c}\text { Cumulative } \\
\text { Percent }\end{array}$ \\
\hline \multirow{4}{*}{ Valid } & & & 32.9 & 32.9 \\
& Agrongly Agreed & 28 & 32.9 & 29.4 & 62.4 \\
& 25 & 29.4 & 9.4 & 71.8 \\
& Undecided & 8 & 9.4 & 23.5 & 95.3 \\
& Disagreed & 20 & 23.5 & 4.7 & 100.0 \\
& Strongly Disagreed & 4 & 4.7 & 100.0 & \\
\hline
\end{tabular}

Source: Survey, 2020.

The table shows that $32.9 \%$ of the respondents strongly agreed that To a great extent government stimulus package is of immense benefit to the organization, $29.4 \%$ of the respondents agreed to the contrary, $9.4 \%$ of the respondents are unsure, $23.5 \%$ of the respondents disagreed to the subjected matter and $4.7 \%$ of the respondents strongly disagreed. This implies that majority of the respondents strongly agreed that to a great extent government stimulus package is of immense benefit to the organization. 
ISSN 2582-2292

Vol. 3, No. 05 Sep-Oct; 2021

An outcome of effective government scheme is increased SME's Growth.

\begin{tabular}{|l|r|r|r|r|}
\hline & Frequency & Percent & Valid Percent & \multicolumn{2}{c|}{ Cumulative } \\
Percent
\end{tabular}

Source: Survey, 2020.

The table shows that $20 \%$ of the respondents strongly agreed that An outcome of effective government scheme is increased SME's Growth, $41.2 \%$ of the respondents agreed to the contrary, $7.1 \%$ of the respondents are unsure, $27.1 \%$ of the respondents disagreed to the subjected matter and $4.7 \%$ of the respondents strongly disagreed. This implies that majority of the respondents agreed that an outcome of effective government scheme is increased SME's Growth.

\section{TEST OF HYPOTHSES}

The Pearson correlation (r) was employed to test the association between the variables stated in the hypotheses at 0.01 level of significant.

Decision Rule: Accept the Alternative Hypotheses and reject the Null Hypotheses if the Pearson correlation ( $r$ ) is positive. The level of strength between this variable can also be determine as indicated in a table below:

\begin{tabular}{|l|l|}
\hline \multicolumn{1}{|c|}{ Coefficient Value } & \multicolumn{1}{|c|}{ Strength of Association } \\
\hline $1.1</ \mathrm{r} /<.3$ & Small correlation \\
\hline $0.3</ \mathrm{r} /<.5$ & Medium/moderate correlation \\
\hline$/ \mathrm{r} />.5$ & Large/strong correlation \\
\hline
\end{tabular}

Where $\mathrm{r}$ means the absolute value of the Pearson correlation coefficient.

\section{HYPOTHESIS ONE}

H1: There is a significant relationship between Capital Structure and SME's Growth. 
ISSN 2582-2292

Vol. 3, No. 05 Sep-Oct; 2021

\section{Correlations}

\begin{tabular}{|ll|r|r|}
\hline & & Capital & SME's Growth \\
\hline \multirow{3}{*}{ Capital Structure } & Pearson Correlation & 1 & .678 \\
& Sig. (2-tailed) & & .000 \\
& $\mathrm{~N}$ & 85 & 85 \\
& Pearson Correlation & .678 & 1 \\
SME's Growth & Sig. (2-tailed) & .000 & \\
& $\mathrm{~N}$ & 85 & 85 \\
\hline
\end{tabular}

Source: Researcher Field work (2020).

The Pearson correlation (r) analysis between capital structure and SME'S growth variables is 0.678, indicating a strong positive correlation between capital structure and SME's growth variables. Thus, the null hypothesis is rejected and it is concluded that There is a significant relationship between Capital Structure and SME's Growth

\section{HYPOTHESIS TWO}

H2: There is a significant relationship between Government Scheme and SME's Growth

Correlations

\begin{tabular}{|ll|r|r|}
\hline & & Government Scheme & SME's Growth \\
\hline \multirow{4}{*}{ Government Scheme } & Pearson Correlation & 1 & $.890^{*}$ \\
& Sig. (2-tailed) & & .000 \\
& $\mathrm{~N}$ & 85 & 85 \\
& Pearson Correlation & $.890^{*}$ & 1 \\
SME's Growth & Sig. (2-tailed) & .000 & \\
& $\mathrm{~N}$ & 85 & 85 \\
\hline
\end{tabular}

**. Correlation is significant at the 0.05 level (2-tailed).

Source: Researcher Field work (2020).

The Pearson correlation (r) analysis between Government Scheme and SME's Growth variables is 0.890, indicating a strong positive correlation between Government Scheme and SME's Growth variables. Thus, the null hypothesis is rejected and it is concluded that there is a significant relationship between Government Scheme and SME's Growth. 


\section{Summary of Findings, Conclusions and Recommendations}

\section{Summary of findings}

The study finds out that there is relationship between capital structure and SME's Growth. This conotes that the size of the assets, the debts, and the equity of the business will determine the growth and survival. Thus, the type of transactions that most SMES engages in can make or retard the growth level of the business. Generally, the assets of SME; s are usually small but the effective utilization of this assets will determine the effective outcome of the capital structure of such business. So as well the loan to equity ratio of the business is important to the survival (i.e growth of the business).

The second findings reveals that there is a relationship between government scheme and SME's growth. By explanation, government scheme is a relieve package that is geared towards the outright growth of SMES thereby boosting and fostering economic activities. The manner and approach the packages are been provided can minimize or maximize the growth of the business this is why government must do all it can to give necessary supports to the SMEs since it is a contributing factor to the Economic growth.

\section{CONCLUSION}

Capital structure financing is crucial to the effect of a business in other words capital financing determines how a business survives in the economy and must be taken serious so as to accomplish positive returns, profits and generation of increased GDP for the nation. However, it is also important to know that aside capital structure/financing of a business, the government must be ready to provide scheme/ relieve packages for SMES to thrive on.

Going by the aforementioned findings, the study therefore concludes that capital structure and government scheme influences SMES growth to a great extent.

\section{Recommendations}

Based on the findings of the study, the study recommends the following points as an aid to revive SMES Growth:

I. Government should provide adequate stimulus and relieve package to SMES so as to enable their businesses thrive. This could be achieved through several scheme and reforms for the benefits of small-scale businesses

II. To have an effective and efficient capital structure or financing for SMES, compulsory levies such as tax, space levy should be reduced to a minimal point so as to assist small scale businesses have adequate capital for investment.

III. Small Scale Business (SBO's) should be given orientation on several ways as to go into a conglomerate activity. This process involves diversification and by fact it is of immense 
benefits and increased capital when small businesses goes into diversification.

IV. Review of assets, equity and debts should be carried out by small scale businesses so as to evaluate and checkmate the bottom line of operating and financing activity of the business.

V. Above all, access to loan and drafts for businesses should be available as this will foster the private sector and there by reducing crime, unemployment and poverty.

\section{REFERENCES}

Aluko S. (1983). "Research in Entrepreneurial Development in Nigeria" In U. Udfo-Aka, (Eds) Management Education for National Development. Lagos: Centre for management Development, pp 86-106

Ajayi S. O. and W.A. Adebisi (2006). The role of SMES in poverty alleviation, Journal of management research, 2(1), 113- 123.

Amuda S. (2006), SMEDAN plan better welfare package for female banker. National Mirror, 8(2), 110.

Akhtar, S., Javed, B., Maryam, A. and Sadia, H., 2012. Relationship between financial leverage and financial performance: Evidence from fuel and energy sector of Pakistan. European Journal of Business and Management, 4(11), pp.7- 17.

Berger, A.N. and Bonaccorsi, P.E., 2006. Capital structure and firm performance: A new approach to testing agency theory and an application to the banking industry. Journal of Banking and Finance, 4(30), pp.1065-1102.

Bohren,O. and Odegaard, B.A., 2000. Corporate governance and economic performance of Norwegian listed firms. Research report II, Norwegian School of Management.

Bauer, P. (2004), Determinants of Capital Structure: Empirical Evidence from the Czech Republic, Czech Journal of Economics and Finance, 54, 2-21.

Berger, A.N \& Wharton, F. (2002). Capital Structure and Firm Performance: A New Approach to Testing Agency Theory and an Application to the Banking Industry.

Chowdhury, A. and Chowdhury, S.P., 2010. Impact of capital structure on firm's value: Evidence from Bangladesh. Business and Economic Horizons, 3(3), pp.111-122

Cho, M.H., 1998. Ownership structure, investment and the corporate value: An empirical analysis. Journal of Financial Economics, 47(4), pp.103-121.

Demsetz, H. and Villalonga, B., 2001. Ownership structure and corporate performance. Journal of Corporate Finance, 7(2), pp.209-233.

Drobetz, W., Roger, F. (2003), What are the Determinants of the Capital Structure? Some Evidence for Switzerland, WWZ/Department of Finance, Working Paper No.4/03.

Dare, F.D. \& Sola, O. (2010). Capital Structure and Corporate Performance in Nigeria Petroleum 
Industry: Panel Data Analysis. Journal of Mathematics and Statistics 6 (2): 168-173.

Fattouh, B., Harris, L., Scaramozzino, P. (2002), Capital Structure in South Korea: A Quantile Regression Approach, Royal Economic Society Annual Conference, 70, 1-34.

Fama, E.F., French, K.R. (2000), Testing Tradeoff and Pecking Order Predictions about Dividends and Debt, The Center for Research in Security Papers, University of Chicago, Working Paper No.506.

Ghosh, A. and Jain, P.C., 2000. Financial leverage changes associated with corporate mergers. Journal of Corporate Finance, 6(3), pp.377-402.

Hadlock, C. and James, C.C., 2002. Do banks provide financial slack? Journal of Finance, 57(4), pp.1383-1419.

Hutchinson, R.W., 1995. The capital structure and investment decisions of the small owner-managed firm: Some exploratory issues. Small Business Economics, 7(3), pp.231-239

Huang, H. and Vu Thi, T., 2003. The determinants of capital structure in shipping companies: Case studies of Brotrom and Concordia. Unpublished Masters thesis, University of Gothenburg, Gothenburg.

Isimoya A. O. (2005), "Nigerian Business Environment; An Introduction", Lagos: Concept Publications Limited, Lagos

Jensen, M. C., \& Meckling, W. H. (1976). Theory of the firm: Managerial behavior, agency costs and ownership structure. Journal of financial economics, 3(4), 305-360.

Kennon, J., 2010. An introduction of capital structure: Why capital structure matters to your investment. Retrieved from www.about.com

Loderer, C. and Martin, K., 1997. Executive stock ownership and performance: Tracking faint traces. Journal of Financial Economics, 45(5), pp.223-255.

Modigliani, F., \& Miller, M. H. (1958). The cost of capital, corporation finance and the theory of investment. The American economic review, 261-297.

Modigliani, F., \& Miller, M. H. (1963). Corporate income taxes and the cost of capital: a correction. The American economic review, 53(3), 433-443.

Myers, S. And Majluf, N., 1984. Corporate financing and investment decisions when firms have information that investors do not have. Journal of Financial Economics, 2(13), pp.187-221.

Obikoya J. O., 1995. "Small and Medium Enterprises (SMEs) in Nigeria: Problems and prospects", in A.T. Ojo (1995) (Eds) Management of Small and medium enterprises in Nigeria (pp. 246-256), Ikeja: Pumark Limited.

Onaolapo, A. A. and Kajola, S.O. (2010). Capital Structure andfirm performance: Evidence from Nigeria. European Journal of Economics, Finance and Administrative Sciences.

Oke, O. S. \& Afolabi, B. (2011). Capital Structure and Industrial Performance in Nigeria. International Business and Management Vol. 2, No. 1. 2011, pp. 100-106 Olowe, R.A., 1998. Financial Management; Concepts, Analysis and Capital Investments. 1st Edn., Brierly Jones Nigeria Ltd, Lagos, pp: 361-391 
Ong, T. S. \& The, B. H. (2011). Capital Structure and Corporate Performance of Malaysian Construction Sector. International Journal of Humanities and Social Science Vol.1No. 2.

Penman, S.H., 2001. Financial statement analysis and security valuation. New York: Mc Graw Hill.

Petersen, M.A. and R. G. Rajan. (1994). The Benefits of Lending Relationship: Evidence from Small Business Data. Journal of Finance 49(1) (1994): 3-37.

Pratomo, W. A. \& Ismail A. (2006). Islamic bank performance and capital structure

Relman, S.S., (2013). Relationship between financial leverage and financial performance: Empirical evidence of listed sugar companies of Pakistan. Global Journal of Management and Business Research Finance, 13(8), pp.33-40.

Raji, I., (2012). Effects of ownership structure on the performance of listed companies on the Ghana Stock Exchange. Unpublished thesis. Retrieved from chss.uonbi.ac.ke

Taub, A.J. (1975), Determinants of the Firm's Capital Structure, The Review of Economics and Statistics, 57(4), 410-416

Zeitun, R. \& Tian, G. G. (2007). Capital structure and corporate performance: evidence from Jordan. Australasian Accounting Business and Finance Journal. Volume I. 